\title{
THE COMBINED EFFECT OF ISLAMIC WORK ETHICS, HIGH- PERFORMANCE WORK PRACTICE, AND PROJECT GOVERNANCE ON PROJECT SUCCESS
}

\author{
Mehwish Ali Khan ${ }^{1}$, Iram $\mathrm{Naz}^{2 *}$, Shoaib Shafique ${ }^{3}$, Syed Danial Hashmi ${ }^{4}$, Mattiullah Farooqi ${ }^{5}$ \\ ${ }^{1,5}$ Lecturer, Riphah International University, Islamabad, Pakistan; ${ }^{2 *}$ Assistant Professor, Riphah International University, \\ Islamabad, Pakistan; ${ }^{3,4}$ Senior Lecturer, Riphah International University, Islamabad, Pakistan. \\ Email: ${ }^{1}$ mehvish.ali@ riphah.edu.pk, ${ }^{2 *}$ iram.naz@ riphah.edu.pk, ${ }^{3}$ shoaib.shafique@ riphah.edu.pk, \\ ${ }^{4}$ danial.hashmi@riphah.edu.pk, ${ }^{5}$ mattiullah.farooqu@ riphah.edu.pk \\ Article History: Received on $18^{\text {th }}$ April 2021, Revised on $15^{\text {th }}$ May 2021, Published on $30^{\text {th }}$ May 2021
}

Abstract

Purpose: This study aims to observe the effect of religion-based work ethics, i.e., Islamic work ethics (IWE) and Highperformance work practices (HPWP), on the success of projects in the development sector of Pakistan. Further, the study proposes project governance as a moderator between IWE, HPWP, and project success.

Methodology: This is a quantitative study and used a convenience sampling technique to collect the data. The data was collected from the project-based organization in Rawalpindi, Islamabad, and Muzaffarabad, and 239 questionnaires were circulated to the employees of project-based organizations. For data analysis, SPSS was used.

Results: Results indicate that IWE and HPWP significantly contribute towards project success. Likewise, the results of moderated regression analysis show that project governance enhances the positive relationship between IWE, HPWP, and project success. These results have been discussed.

Practical Implications: The results carry significant implications for managers of project-based organizations. Our results point towards the importance of work ethics, high-performance work practices, and governance mechanisms towards the success of projects. Managers should thus be vigilant toward these mechanisms.

Originality: The contribution of this study is that first time we see the impact of Islamic work ethics on project success. Islamic work Ethics is an essential and worthwhile concern for an organization because it allows employees to work honestly and ethically to achieve project success.

Keywords: High-performance Work Practices, Islamic Work Ethics, Project Governance, Project Success, Project-based Organization.

\section{INTRODUCTION}

Positive project outcome, i.e., the success of the project, is the ultimate quest of any project manager and thus appears to be the most widely studied variable in the field of project management. Traditionally, the project's success has been studied in light of the triple constraint model i.e., cost, time, and performance (Koops et al., 2016). However, recently researchers have started noting that the triple constraint model alone is not sufficient to explain the success/failure of any project (IrimiaDieguez et al., 2015). Literature has started acknowledging that many intangible factors (individual and organizational) can play a vital role in making projects successful (Müller \& Turner, 2007; Zwikael \& Smyrk, 2011).

Seligman and Csikszentmihalyi (2014) identified spirituality and forgiveness of project team members as essential success factors at individual and organizational citizenship behavior, selflessness, and work ethics as important success factors at the organizational level. Among others, one of the most critical factors that can influence project success is applying highperformance work practices within organizations (Posthuma et al., 2013). Previous research has shown that highperformance work practices create a pleasant work environment within project-based organizations and help to make projects successful (Huemann et al, 2007; Zupan \& Kaše, 2007).

Similarly, in the post-Enron era, workplace ethics has become a significant driver of success within organizational boundaries. For the enhancement of the ethical environment within organizations, researchers have given prime importance to propagating religion-driven values at the workplace (Parboteeah et al., 2009). Islamic work ethics (initiated by Ali, 1998) is one type of religion-driven work ethic. It is based on the teachings of the Quran (Muslim's Holy Book) and Hadith (Sayings of Prophet Muhammad PBUH). Research has shown that there is positive relationship exists between Islamic work ethics and organizational performance. According to the Islamic work ethics concept, the central role of an individual is to use an adequate amount of his/her energy in work. Socialization at work is encouraged to manage personal and work life. Work itself is considered as a means of creating an independent self-identity, self-respect, personal growth, and satisfaction (Imam et al., 2013). 
Thus, we believe that high-performance work practices at the organizational level and Islamic work ethics at the organizational level but promoted at the individual level can play an essential role in determining project success. Our thought is in line with Khan and Rasheed (2016), who argued that the inspirations of Islam in light of human resource practices could be an exciting mix for the success of project-based organizations. Though we agree with this notion yet, we believe that Islamic work ethics (because of their inherent characteristics) can influence the success of projects and doesn't necessarily need to moderate the relationship between work practices and project success. This thought is also in line with Usman et al., (2015), who argued that Islamic work ethics should be tested independently with other variables.

Specifically, in countries like Pakistan, where $97 \%$ of the population is Muslim, and religion is considered a supreme authority, it is evident that Islamic work ethics can be a potential source of project success. However, in emerging countries like Pakistan, the biggest issue is governance both at the national and organizational levels. Pakistan is one of the poorly governed countries with a high corruption rate. In the absence of strong governance mechanisms, religion-driven work ethics and high-performance work practices can't guarantee the success of projects. Thus we believe that strong governance mechanisms will boost the relationships between project success and HPWP and IWE and project success in the Pakistani scenario.

This research aims to fill the research gap by addressing the influence of HPWP and IWE on project success. Project governance is not addressed as before with Islamic work ethics. Moreover, few studies were carried out by considering IWE as an independent variable with project success. Many papers have discussed Islamic work ethics as moderator and mediator. Still, no one has discussed the impact of Islamic work ethics and high performance on project success with the moderating role of top project governance. This research aims to see the effects of IWE and HPWPs on project success with the moderating role of project governance in different industries, especially in private organizations.

\section{LITERATURE REVIEW}

\section{Project Success}

Researchers have been trying to understand the concept of project success and the aspects which make projects successful since the 1970s ( $\underline{\mathrm{Ika}, 2009)}$. The last four decades of research on the subject matter have recognized the variation in success factors that can be functional through a project's life cycle to improve the likelihoods of success (Müller \& Jugdev, 2012). Despite the enormous effort and work in the area, there is no unanimously accepted definition of project success. There are different viewpoints as to what makes a project successful and how. The criteria for measuring the project success vary with the change in nature, complexity and size of the projects (Mir \& Pinnington, 2014), the contract of the project, kind of project, and personality of project team member (Müller \& Jugdev, 2012). Historically, the iron triangle has been used to measure project success. This means that the success of a project depends on how efficiently and effectively it is managed concerning cost, time, and quality (Papke-Shields et al., 2010; Pinto \& Pinto, 1990). Researchers have criticized this iron triangle criterion of measuring success as being static and unable to work well with complex projects (Mullaly, 2006).

Definition of successful projects has changed or got enhanced over time. Pinto and Pinto (1990) designed a framework for success that contains the effectiveness of the organization, technical and organizational rationality. Freeman and Beale (1992) argued that success depends on execution, efficiency, technical performance, organizational implications, managerial implications, productivity, personal development, and business progress. Shenhar et al. (2001) argued that every project has its peculiar requirements and needs diverse success factors. These factors rely on the idea of the project and its objectives. Researchers have recognized the importance of behaviors and soft skills in determining the success of the project. Previous research has outlined some critical factors, such as (i) environment-related aspects e.g., the location where the project is being performed (Fortune \& White, 2006; Hyväri, 2006; Jha \& Iyer, 2006), people related aspects (Tishler et al., 1996), aspects related to the procedure and tools (Andersen et al., 2006; Khang \& Moe, 2008; Shenhar et al., 2001) and the contextual aspects (Sauser et al., 2009) that could impact project success.

\section{Islamic Work Ethics and Project Success}

From the last decade, the most debating topic in research is ethics. Due to ethical problems, many international scandals arise; the main reason for these scandals is the lack of transparency in corporate governance. Organizations start to train their employees on ethical behavior at work. The people who work in organizations have argued that the critical factor through which an organization can avoid crises in the future is the ethical competency of the employees. It is essential to understand the impact of the working environment on behavior because it is related to ethical problems in the working environment of the project (Müller et al., 2013). According to Buchholz and Rosenthal (1996), ethics is the actions implemented by the people in a specific situation. Ethical behavior refers to the condition in which, between the two alternatives, one has to choose what is right and what is wrong (Walker \& Lloyd-Walker, 2014). According to Müller et al., (2016), in project-based organizations, the ethical problems vary according to the firms' corporate governance framework. 
In the field of management, ethics is the new domain. Normative ethics is the binding domain which means what specific action should be taken in a situation. Müller et al. (2013), and Walker and Lloyd-Walker (2014), identified the ethical problems raised in the project-based organization. Few studies provide evidence that why an individual act unethically at his/her workplace.

The word ethics emerges from Islam, so the term Islamic work ethics is first used by Othman et al., (2004); they believe that work-related ethics are usually driven by religion. According to Pettijohn et al. (2008), every person can differentiate between good and evil. The recognition of good and bad is essential in the context of Islamic work ethic. At the individual and organization level, the organization's focus is on the progress of positive organizational psychology (Meyers et al., 2013).

The concept of Islamic work ethics is based upon the teaching of the Quran and Sunnah (Ali \& Al-Owaihan, 2008; Yousef, 2000). As compare to other religious teachings on work ethics, researchers state that Islamic work ethics is a broad thought and it is not specified to the limited people (Khan et al., 2015). As religion is the individual's private practice, Islamic work ethics influence the good or evil act of the individual. According to the above discussion, we proposed the following hypothesis:

H1: Islamic work ethics has a significant positive impact on project success.

\section{High-Performance Work Practices and Project Success}

In a project-based organization, the role of human resource management has a significant role important. The organization needs to make proactive-based policies rather than passive based. To make a project successful, it is necessary to align strategies according to the need of the project (Huemann, 2010). The word project success means reached at your desired targets by applying the most appropriate strategies relevant to the organization's services or product. The management team's success is measured by matching the goals they achieved with budgeted/planned goals (Müller \& Turner, 2010).

The success of the project depends upon the management. Specifically, the human resource management working practices are crucial in determining the project's success. It is positively related to the performance of the organization. It is necessary for the project-based organization to properly adjust the human resource practices according to the need of the project (Huemann et al., 2007). According to Olateju et al., (2018), best human resources practices have a positive effect on the project's success.

Moreover, they also revealed that project-oriented training and continuous feedback also encourage proactive behavior, ultimately affecting the project's effectiveness. In a project-based organization, human resources management and its practices are a very important part. Based upon the previous researches we can hypothesize that:

H2: High-performance work practices have a significant positive impact on project success.

\section{Project Governance and Project Success}

Governance can be defined in varying terms depending upon its possibility and concentration, for example, the governance of projects, project governance, and societal governance. Governance plays a vital role at many different stages, like governance of tasks in groups, regarding the portfolios of projects or programs. Here, governance has been fixated as the collective governance, known as governance of projects (Müller \& Lecoeuvre, 2014). Project governance needs to be taken and absorbed as the circumstantial element as corporate governance occurs parallel to the times when the foundations of the organizations are laid formally. Project governance has transformed the person's stance, views, opinions, and interpretations regarding project management. This happened because project governance offers the outline to start, perform, and control the projects (Turner, 2006). Governance has an indirect effect on the people concerning the supervisor who administered them and imposes a direct impact through indirect organizational forces that form the social order of the environment people live in and how they work (Foucault, 1991). Governance interrelates with the legislation and the situational factors and has an essential standing in almost every walk of life; perhaps, activities of teams and groups of people are not easy to be governed through it (Clegg et al., 2002). Governance can be described in varying terms as far as its overall range and focus is concerned. Like other forms of governance, during the life cycle of projects, it plays its significant role at almost every level, like the governance of several projects in terms of the portfolios of projects or programs. Here, governance was more of the form of collaborative governance. Müller and Lecoeuvre (2014) viewed it as the governance of projects. According to Ma et al. (2020) for the success of the project well defined governance arrangements are important factor.

Explanation of governing some projects is unlike the governance of a solo project as per the definition by Pinto and Pinto (1990). The notion of project governance relates to the use of systems, authority \& processes to arrange for the funds and synchronize or exercise projects' actions. Governing of a project is shared with the project governance. Being the subgroups of the overall framework of corporate governance, it deals with the programs governance, portfolios, and projects (Müller \& Lecoeuvre, 2014). Past research done on project governance provides an insight into the numerous perspectives, like that of 
the risk distribution through the application of project governance (Abednego \& Ogunlana, 2006), the framework for exploring the development and completion of the large participated projects (Müller \& Turner, 2007), precise structure of the project defined by NASA (Shenhar et al., 2001), governance of projects processes (Winch, 2001), practicing governance in the project-based firms (Keegan \& Turner, 2001), directives of nonconformity (Pinto \& Pinto, 1990), governance in different types of organizations like functional organizations, matrix-based organizations and those of projectile organizations (Müller \& Lecoeuvre, 2014).

Project governance should be taken as the relative factor because of corporate governance since the time of starting of organization. It has improved the opinions of individuals and their views over project management. It's because project governance lays the road map to initiate, implement, run, and monitor the projects (Turner, 2006). To understand the association between the success and governance of a project, a layout is required to portray the organization's governance framework. Instead of this, many different models were planned with diverse perspectives like top-down and bottom-up methodology (Klakegg, 2009). The top-down viewpoint covers the stakeholders and outcomes, whereas the bottom-up perspective refers to the process control perspective (Muller, 2011). The model of governance is established on the transaction cost economic theory, the agency theory, the institutional theory. The model presented well-defined classes of governance, named as the paradigms. So, if an organization goes for any specific project, it opts for any defined four categories. The categories have two coordinates. Corporate governance orientation was tossed concerning the models introduced by Clarke (2004) and Hernández-Madrigal et al., (2012). The importance of project governance regarding project success was controlled in the qualitative case studies led in South Africa by using diverse qualitative research techniques. People interviewed during the survey held the opinion that the principles of governance exerted a substantial impact on the project's success (Bekker \& Steyn, 2008). Derived from these studies, it is established that project governance has an essential role in the project's success.

H3: Project Governance has a significant positive impact on project success.

\section{The moderating role of project governance between Project Success and IWE}

The governance presumes in all walks of life and works together with the situational structures and the legislation; perhaps, people teamed up as groups and teams cannot be administered through it (Clegg et al., 2002). A standardized framework for reporting is required, as managers do not wish to highlight the bad news and remain silent on purpose. Gulati and Nickerson (2008) view the framework of governance to be giving a complete picture of the role being played in the ethical issues of project-based organizations. Governance provides a framework to the management whose underneath is projects being implemented; for a project-based organization, the adjacent governance is recognized as a steering group (Müller \& Lecoeuvre, 2014). Scholars differ in opinions about the fairness of governance of project-based organizations. However, corporate governance heads the activities in corporations as a whole encompassing governance of project-based organizations as well (Too \& Weaver, 2014), Although few authors believe project-based organizations to be independent and work as representatives of resource consumption (Müller et al., 2013), and may not be wholly administered by corporate governance and governance of project-based organizations at the macro and the micro levels respectively. The practices observed in successful organizations show that Islamic work ethics is a significant moderator (Marri et al., 2012; Müller et al., 2013). Islamic work ethics influence the success and failures of individuals who take religion as their private practice (Rice, 1999). Project governance has not been addressed before with Islamic work ethics. However, few studies have been conducted taking IWE as an independent variable alongside project success. Islamic work ethics has been discussed as a moderator/ mediator variable in much research work. Still, no one has addressed the Impact of Islamic work ethics and high performance on the project's success, with top project governance being the moderator. This makes this study an excellent attempt to explore the said relationship. So, following hypothesis is assumed to be true.

H4: Project governance moderates the positive association between Islamic work ethics and project success such that it will be strong when project governance is high.

\section{The moderating role of project governance between Project Success and HPWPS}

There have been many theories of management that are applied in the field of project governance. Due to collapse

of many corporations in the 1980s, the importance of corporate governance has increased. Moreover, the economist is also interested in the organizations' decision-making process (Gilson \& Milhaupt, 2005). Gilson and Milhaupt (2005) presented that the economists considered that there could be a possibility of a relationship existing between governance and performance of the organizations. Considering the above viewpoint, management theories are applied by the researchers to discover the features that affect performance and project governance in an organization (Maher \& Andersson, 2000).

According to Bekker and Steyn (2008), the principles of governance have a positive and significant impact on the project's success. They proposed that governance plays a vital role in project success. Some studies have taken project governance as a mediator and find significant impact (Kaminsky \& Zerjav, 2016; Müller et al., 2016). 
This study tries to find out the mediating role of governance on project success in different sectors. However, in the Literature, the image about the relationship between project success and behavioral control orientation is very hazy. On the other hand, the Literature on the maturity of the project model represented by PMI (2013) stresses the importance and implications of the governance for project success.

Elahi et al., (2020) suggested that the mediation of project governance in the relationship of HPWPs with project success is not significant, and it only partially mediates the relationship in project-based organizations. So, in this study, the moderation of project governance between the linages of HPWPs and project success needs to be tested.

H5: Project governance moderates the positive association between HPWPs and project success such that it will be strong when project governance is high.

\section{METHODOLOGY}

\section{Data and Procedure}

A cross-sectional design was adopted to conduct the study. Khan and Rasheed (2015) argued that cross-sectional design appears to be a superior design for getting a fair description of project-based organizations. Three organizations working in twin cities, i.e., Islamabad/Rawalpindi and Muzaffarabad (Pakistan held Kashmir), were selected. The selection of these cities is based on the fact that these are the capital cities of Pakistan and Pakistan held Kashmir. The majority of projectbased organizations are working in these cities because of ongoing developmental projects. To get a fair picture of the overall project-based organizations, we selected one public and two private organizations. 300 employees of these organizations were surveyed using an on-site administered, self-reported questionnaire in which respondents were asked about their perceptions about work practices, project success, project governance and Islamic work ethics within their organizations. We received 256 questionnaires, out of which only 239 were found usable, i.e., $79.67 \%$ response rate. Out of these 239 respondents, $67.8 \%$ were male, and $32.2 \%$ were female. $12.5 \%$ of respondents had 12 years of primary education, $27.2 \%$ had a $14-$ year education degree, and $40.2 \%$ respondents were masters qualified, whereas $20.1 \%$ were MS (18 years education) qualified. Regarding work experience, $12.6 \%$ of respondents had a work experience of 5-10 years, $74.9 \%$ had an experience of 11-16 years, whereas $12.6 \%$ had experience above or equal to 17 years. We used MPLUS 7.0 and SPSS 21 as tools for data analysis.

\section{Measures}

Different scales were adopted to measure the responses of individuals. We conducted a confirmatory factor analysis to test the accuracy of the scales (because they were developed in other cultures and countries) and overall model fitness. Results of CFA are reported below in Table-1. Model fitness indices show that overall model is fit to be studied $\left(\mathrm{X}^{2} / \mathrm{d}\right.$.f. $=3.54$, $\mathrm{GFI}=0.801, \mathrm{CFI}=0.86, \mathrm{RMESA}=0.341, \mathrm{SRMR}=0.032$ ). These values of modification indices are reported after excluding items whose factor loading was less than 0.50 , as reported in table-1.

\section{Project Success}

Aga et al., (2016) four items scale was used to measure project success. A sample item is "The project was completed on time." Factor analysis revealed that the loading of one item is less than 0.5. Thus the item was excluded from the analysis. Construct reliability of the scale was 0.81 .

\section{Project Governance}

The ten-item scale of Müller et al. (2016) was adapted to measure project governance. A sample item is "In my organization, a strong emphasis is on always getting personnel to follow the formally laid down procedures." After factor analysis, five items were excluded. Construct reliability of the scale is 0.77 .

Table 1: Confirmatory factor Analysis

\begin{tabular}{lllll}
\hline Item & \multicolumn{4}{l}{ Variable (factor loadings) } \\
& PS & PG & HPWP & IWE \\
\hline PS1 & 0.719 & & & \\
\hline PS2 & 0.364 & & \\
\hline PS3 & 0.824 & & \\
\hline PS4 & 0.766 & & \\
\hline PG1 & & 0.319 & \\
\hline PG2 & & 0.526 & \\
\hline PG3 & & 0.531 & \\
\hline PG4 & & 0.35 & \\
\hline
\end{tabular}




\begin{tabular}{|c|c|c|c|c|}
\hline PG5 & & 0.313 & & \\
\hline PG6 & & 0.517 & & \\
\hline PG7 & & 0.533 & & \\
\hline PG8 & & 0.335 & & \\
\hline PG9 & & 0.744 & & \\
\hline PG10 & & 0.336 & & \\
\hline PG11 & & 0.738 & & \\
\hline HP1 & & & 0.591 & \\
\hline HP2 & & & 0.614 & \\
\hline HP3 & & & 0.526 & \\
\hline HP4 & & & 0.479 & \\
\hline HP5 & & & 0.500 & \\
\hline HP6 & & & 0.506 & \\
\hline HP7 & & & 0.679 & \\
\hline HP8 & & & 0.724 & \\
\hline HP9 & & & 0.676 & \\
\hline HP10 & & & 0.676 & \\
\hline HP11 & & & 0.499 & \\
\hline HP12 & & & 0.223 & \\
\hline HP13 & & & 0.025 & \\
\hline HP14 & & & 0.073 & \\
\hline IWE1 & & & & 0.119 \\
\hline IWE2 & & & & 0.489 \\
\hline IWE3 & & & & 0.256 \\
\hline IWE4 & & & & 0.734 \\
\hline IWE5 & & & & 0.781 \\
\hline IWE6 & & & & 0.033 \\
\hline IWE7 & & & & 0.108 \\
\hline IWE8 & & & & 0.065 \\
\hline IWE9 & & & & 0.01 \\
\hline IWE10 & & & & 0.358 \\
\hline IWE11 & & & & 0.672 \\
\hline IWE12 & & & & 0.595 \\
\hline IWE13 & & & & 0.604 \\
\hline IWE14 & & & & 0.638 \\
\hline IWE15 & & & & 0.521 \\
\hline IWE16 & & & & 0.021 \\
\hline IWE17 & & & & 0.129 \\
\hline$A V E$ & 0.594 & 0.368 & 0.511 & 0.428 \\
\hline $\boldsymbol{C R}$ & 0.814 & 0.773 & 0.902 & 0.838 \\
\hline \multicolumn{3}{|c|}{ Relative / Normal chi-square (CMIN/ DF) } & 3.54 & \\
\hline \multicolumn{3}{|c|}{ Goodness Fit Index (GFI) } & 0.701 & \\
\hline \multicolumn{3}{|c|}{ Comparative Fit Index (CFI) } & 0.71 & \\
\hline \multicolumn{3}{|c|}{$\begin{array}{l}\text { Root Mean Square Error of Approximation } \\
\text { (RMSEA) }\end{array}$} & 0.341 & \\
\hline \multicolumn{3}{|c|}{ Standardized Root Mean Residual Square(SRMR) } & 0.072 & \\
\hline
\end{tabular}

PS=Project Success, PG=Project Governance, HPWP=High Performance Work Practices, IWE=Islamic Work Ethics, $\mathrm{AVE}=$ Average variance extracted, $\mathrm{CR}=$ Construct reliability.

Source: Authors

\section{High-performance work practices}

Fourteen items scales of Wickramasinghe and Liyanage (2013) were adopted to measure this variable. After factor analysis, only nine items were retained for further analysis. Overall construct reliability of the scale was 0.90 . The sample item is "Your organization provides specified examples of expected performance during performance review discussions". 
Islamic work ethics

We used a 17 item scale to measure Islamic Work Ethics, developed by Ali (1988). Due to poor factor loadings, we exclude ten items from the scale, and seven items were retained for further analysis. Construct reliability of the scale was 0.83 .

\section{Control Variables}

One-way ANOVA analysis was performed to identify the potential effect of demographic variables. No demographic variable was found to cause any distortion in study variables based on F statistic.

\section{RESULTS AND DISCUSSION}

\section{Descriptive analysis and correlation:}

Table 2 summarizes descriptive statistics and correlation analysis.

Table 2: Means, Standard Deviations, Correlations and Reliabilities

\begin{tabular}{lllllll}
\hline \multicolumn{1}{l}{ Mean } & Std. Deviation & 1. & 2. & 3. & 4. \\
\hline Age & 3.17 & 0.75 & & & & \\
\hline Gender & 1.32 & 0.46 & & & & \\
\hline Qualification & 3.67 & 0.94 & & & & \\
\hline Experience & 2.00 & 0.50 & & & & \\
\hline 1. PS & 3.59 & 0.69 & $(.72)$ & & \\
\hline 2. PG & 3.77 & 0.48 & $.756^{* *}$ & $(.79)$ & & \\
\hline 3. HPWP & 3.75 & 0.46 & $.497^{* *}$ & $.567^{* *}$ & $(.81)$ & \\
\hline 4. IWE & 3.67 & 0.38 & $.624^{* *}$ & $.642^{* *}$ & $.693^{* *}$ & $(.74)$ \\
\hline
\end{tabular}

${ }^{* *} \mathrm{P}<0.05, \mathrm{n}=239, \mathrm{PS}=$ Project Success, P.G. = Project Governance, HPWP $=$ High-Performance Work Practices, IWE $=$ Islamic Work Ethics, cronbach alpha is reported in bracket.

Source: Authors

Table indicates a positive significant correlation between Islamic work ethics and project success $(\mathrm{r}=.624, \mathrm{p}<0.05)$, IWE and HPWP $(r=.693, p<0.01)$. The table also shows that HPWP is positively and significantly correlated with project success $(r=$ $.497, \mathrm{p}<0.05)$. Project governance is also positively and significantly correlated with project success $(\mathrm{r}=.756, \mathrm{p}<0.05)$. These results provide initial support to the hypotheses of the study.

\section{Moderated Regression Analysis}

Table 3 shows that IWE positively and significantly impacts project success $(\beta=.45 p<0.001)$. This supports hypothesis H1. It can also be seen in the table that high-performance work practices are also positively and significantly related to project success $(\beta=.31 \mathrm{p}<0.10)$, thus supporting hypothesis $\mathrm{H} 2$.

Table 3: Moderation Analysis

\begin{tabular}{llll}
\hline Predictor & \multicolumn{3}{l}{ Project Success } \\
\hline & $\boldsymbol{\beta}$ & $\mathbf{R}^{2}$ & $\Delta \mathbf{R}^{\mathbf{2}}$ \\
\hline Step I: & & & \\
\hline Islamic work ethics & $0.45^{* * *}$ & & \\
\hline High-performance work practices & $0.31^{*}$ & & \\
\hline Project Governance & $0.87^{* * *}$ & 0.605 & 0.605 \\
\hline Step II: & & & \\
\hline Islamic Work Ethics x Project governance & $1.49^{* * *}$ & & \\
\hline High performance work practices x Project governance & $0.56^{* *}$ & 0.681 & 0.077 \\
\hline$* * * \mathrm{p} \leq .001,{ }^{* *} \mathrm{p}<.05,{ }^{*} \mathrm{p}<0.1, \mathrm{n}=239$ & & & \\
\hline
\end{tabular}

For moderation analysis, interaction terms were made and tested, as shown in table 3 . The result of moderation analysis indicates that Project governance amplifies the IWE and project success association to strengthen the existing relationship. This can also be seen in figure 1, where we have plotted an interaction graph for the connection. This supports hypothesis H3. Similarly, results of moderation analysis also show that project governance moderates the HPWP and project success linkage to amplify the existing relationship. This can be seen in the interaction plot shown in figure 2 . 


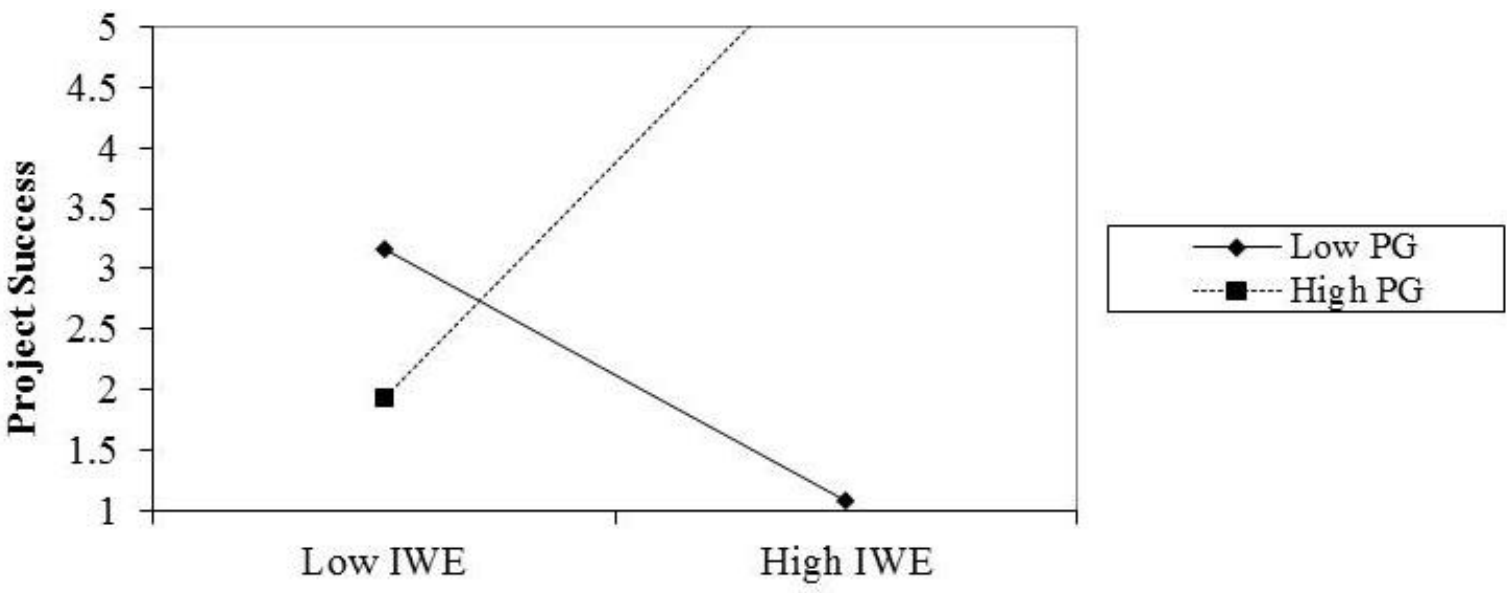

Figure 1: Interactive effects of IWE and project governance on project success

Source: Authors

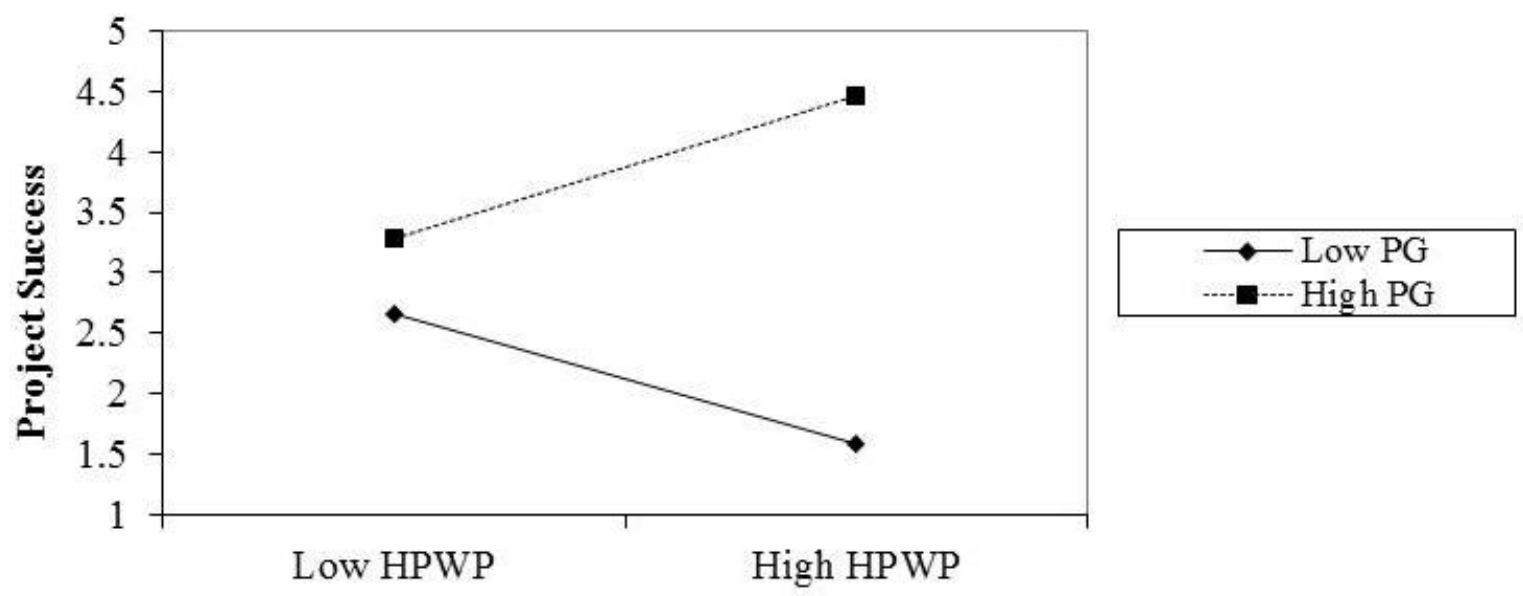

Figure 2: Interactive effects of HPWP and project governance on project success

Source: Authors

Based upon the past studies and data collected from the workforce of diverse organizations of public sectors, where practices of human resources management are implemented impact the success of the project in the corporate and cultural setting of Pakistan. The study aimed to assess the relationship of IWE, project governance, and HPWP on project success. According to correlation and regression results, there is a positive and significant relationship between IWE and project success. These results are in line with the prior work of Khan and Rasheed (2015). According to their study, IWE moderates the relationship between project success and human resource management practices in the project-based organization of Pakistan. To test moderation, we have first to test the relationship between the dependent variable and moderator. The findings are in line with the study of Elahi et al. (2020); according to her, IWE moderates the relationship between HPWP and project success.

The second hypothesis of the study is that there is a positive impact of HPWP on project success. Results indicate that the relationship exists between HPWP and project success. However, the result of regression analysis indicates a significant relationship between these two variables. According to the literature, there is a strong impact of HPWP on the completion of the anticipated outcomes (Belout \& Gauvreau, 2004). According to Belout and Gauvreau (2004), there is a significant relationship between project success and HPWP. These results are consistent with the past study of Pinto and Pinto (1990). Our research results contradict the other studies (Geoghegan \& Dulewicz, 2008; Keegan \& Turner, 2001; Khan \& Rasheed, 2015; Müller \& Turner, 2010).

The third hypothesis, H3, states a positive association between project governance and project success. The correlation and regression analysis results show that the relationships between these two variables are positive and significant. These results also support the previous Literature (Crawford et al., 2008; Klakegg, 2009). According to the study of (Müller et al., 2016), 
there is a significant and positive link between project governance and project success because good governance leads to auspicious outcomes.

The fourth hypothesis, H4, states that project governance strengthens the relationship between Islamic work ethics and project success. According to the moderated regression results, project governance moderates the IWE and project success association. The finding of this hypothesis is similar to prior studies that recommended that there is a direct relationship between IWE and project governance on project success. (Aubry \& Hobbs, 2011; Crawford et al., 2008; Klakegg, 2009; Marri et al., 2012; Müller et al., 2016; Rice, 1999; Tishler et al., 1996). This study first time tested the moderated role of project governance between IWE and project success.

The fifth hypothesis, H5, states that project governance strengthens the HPWP and project success association. Results of moderated regression show that moderated role of project governance between HPWP and project success is significant. Importantly, before moderation, there was not any significant impact of HPWP on project success which indicates that project governance is the reason for developing the relationship between HPWP and project success. So, hypothesis 5 is supported as extant literature suggested the direct effects of HPWP and project governance on project success (Crawford et al., 2008; Klakegg, 2009; Schwaber, 2004; Turner, 2006). But the moderation of project governance is less often tested between the relationship of Islamic work ethics and project success. The findings pronounce the moderating role of governance, as it does develop and strengthen the ties between HPWP and project success. This shows that H5 is supported.

The research aims to study the impact of IWE and HPWP on project success by moderating the role of project governance. The result of the study shows that all the objectives of the study are attainable and are consistent with the literature.

\section{CONCLUSION}

Study at hand, the association between HPWP and IWE on project success with the moderating role of project governance was examined. The primary purpose of this study was to find out the impact of IWE on project success. The study also has explained the moderating effect of project governance between the relationship of ethics, work practices, and success. This study has also contributed to the earlier literature, as little work on IWE as an independent variable exists. In sum, in this study, five hypotheses have been analyzed. All Hypotheses are accepted and consistent with previous studies.

The data were collected, from 239 respondents, through questionnaires from project-based organizations located in Twincities and Muzaffarabad (A.K.). This study concludes that project governance's moderating effect on project success is vital and HPWP and IWE foster project success. This study contributes to project management literature, as little scholarly work is available in this stream of research. Our study pronounces the impact of IWE, HPWP, and project governance on project success. The study also offers practical insights for project managers. Specifically, this research highlights the role of project governance, IWE, and HPWP will contribute to the increase in the possibility of project success.

Moreover, the study recommends that future studies may be carried out in the different project and public based organizations and in developed and developing countries by increasing the sample size with the same variables to verify the moderated relationship of project governance between HPWP and IWE on project success and in so doing, they can enhance the generalizability of the present study.

\section{LIMITATION AND STUDY FORWARD}

This study has few limitations, like a small sample size. Furthermore, this study may also be debate via a qualitative technique such as interviews or case studies. In this study, a cause and effect relationship was used, and this relationship cannot be concluded from these results because the study applies the cross-sectional data. Private-based organizations would be chosen (longitudinally data) in the future to see the moderated effect of project governance between Islamic work ethics and project success and between high-performance work practices and project success progress over time. Secondly, this study focuses on presumed variables. Many other factors can impact project success, along with Islamic work ethics. Future studies may be carry in different project and public based organizations and in developed and in developing countries by expanding the large sample size with the same variables to verify the moderated relationship of project governance between high-performance work practices and Islamic work ethics on project success and to strengthen the concepts in this study.

\section{ACKNOWLEDGEMENT}

We want to thank Dr. Zeshan Ghafoor, Associate Dean RARE, for supporting data collection.

\section{AUTHORS CONTRIBUTION}

Ms. Mehvish Ali Khan generated the idea and contributed to model development and data analysis. Mr. Syed Danial Hashmi contributed to the introduction part. Dr. Iram Naz and Shoaib Shafique worked on Literature and discussion; both were also involved in addressing and submitting the revision. Mr. Mattiullah Farooqi collected data and proofread the paper. 


\section{REFERENCES}

1. Abednego, M. P., \& Ogunlana, S. O. (2006). Good project governance for proper risk allocation in public-private partnerships in Indonesia. International Journal of Project Management, 24(7), 622-634. https://doi.org/10.1016/j .ijproman.2006.07.010

2. Aga, D. A., Noorderhaven, N., \& Vallejo, B. (2016). Transformational leadership and project success: The mediating role of team-building. International Journal of Project Management, 34(5), 806-818. https://doi.org/10.1016/j.ijproman.2016.02.012

3. Ali, A. (1988). Scaling an Islamic work ethic. The Journal of Social Psychology, 128(5), 575-583. https://doi.org/ $10.1080 / 00224545.1988 .9922911$

4. Ali, A. J. (1992). The Islamic work ethic in Arabia. The Journal of psychology, 126(5), 507-519. https://doi.or $\mathrm{g} / 10.1080 / 00223980.1992 .10543384$

5. Ali, A. J., \& Al-Owaihan, A. (2008). Islamic work ethic: a critical review. Cross cultural management: An international Journal, 15(1), 5-19. https://doi.org/10.1108/13527600810848791

6. Andersen, E. S., Birchall, D., Jessen, S. A., \& Money, A. H. (2006). Exploring project success. Baltic journal of management, 1(2), 127-147. https://doi.org/10.1108/17465260610663854

7. Aubry, M., \& Hobbs, B. (2011). A fresh look at the contribution of project management to organizational performance. Project management journal, 42(1), 3-16. https://doi.org/10.1002/pmj.20213

8. Bekker, M. C., \& Steyn, H. (2008). The impact of project governance principles on project performance. Paper presented at the PICMET'08-2008 Portland International Conference on Management of Engineering \& Technology. https://doi.org/10.1109/PICMET.2008.4599744

9. Belout, A., \& Gauvreau, C. (2004). Factors influencing project success: the impact of human resource management. International Journal of Project Management, 22(1), 1-11. https://doi.org/10.1016/S0263-7863(03)00003-6

10. Buchholz, R. A., \& Rosenthal, S. B. (1996). Toward a new understanding of moral pluralism. Business Ethics Quarterly, 263-275. https://doi.org/10.2307/3857459

11. Clarke, T. (2004). Theories of corporate governance. The Philosophical Foundations of Corporate Governance, Oxon.

12. Clegg, S. R., Pitsis, T. S., Rura-Polley, T., \& Marosszeky, M. (2002). Governmentality matters: designing an alliance culture of inter-organizational collaboration for managing projects. Organization studies, 23(3), 317-337. https://doi.org/10.1177/0170840602233001

13. Crawford, L., Cooke-Davies, T., Hobbs, B., Labuschagne, L., Remington, K., \& Chen, P. (2008). Governance and support in the sponsoring of projects and programs. Project management journal, 39(1_suppl), S43-S55. https://doi.org/10.1002/pmj.20059

14. Elahi, M., Ahmad, M. S., \& Aamir, M. F. (2020). Human resource management practices and project success in hydel projects of Pakistan: moderation of Islamic work ethics and country of origin. Middle East Journal of Management, 7(5), 425-451. https://doi.org/10.1504/MEJM.2020.109680

15. Fortune, J., \& White, D. (2006). Framing of project critical success factors by a systems model. International Journal of Project Management, 24(1), 53-65. https://doi.org/10.1016/j.ijproman.2005.07.004

16. Foucault, M. (1991). The Foucault effect: Studies in governmentality: University of Chicago Press.

17. Freeman, M., Beale P. (1992), "Measuring Project Performance". Project Management Journal, 23, 8-17.

18. Geoghegan, L., \& Dulewicz, V. (2008). Do project managers' leadership competencies contribute to project success? Project management journal, 39(4), 58-67. https://doi.org/10.1002/pmj.20084

19. Gilson, R. J., \& Milhaupt, C. J. (2005). Choice as regulatory reform: The case of Japanese corporate governance. The American Journal of Comparative Law, 53(2), 343-377. https://doi.org/10.1093/ajcl/53.2.343

20. Gulati, R., \& Nickerson, J. A. (2008). Interorganizational trust, governance choice, and exchange performance. Organization science, 19(5), 688-708. https://doi.org/10.1287/orsc.1070.0345

21. Hernández-Madrigal, M., Blanco-Dopico, M.-I., \& Aibar-Guzmán, B. (2012). The influence of mandatory requirements on risk disclosure practices in Spain. International Journal of Disclosure and Governance, 9(1), 7899. https://doi.org/10.1057/jdg.2011.22

22. Huemann, M. (2010). Considering Human Resource Management when developing a project-oriented company: Case study of a telecommunication company. International Journal of Project Management, 28(4), 361-369. https://doi.org/10.1016/j.ijproman.2010.02.008

23. Huemann, M., Keegan, A., \& Turner, J. R. (2007). Human resource management in the project-oriented company: A review. International Journal of Project Management, 25(3), 315-323. https://doi.org/10.1016 /j.ijproman.2006.10.001

24. Hyväri, I. (2006). Success of projects in different organizational conditions. Project management journal, 37(4), 3141. https://doi.org/10.1177/875697280603700404 
25. Ika, L. A. (2009). Project success as a topic in project management journals. Project management journal, 40(4), 619. https://doi.org/10.1002/pmj.20137

26. Imam, A., Abbasi, A. S., \& Muneer, S. (2013). The impact of Islamic work ethics on employee performance: testing two models of personality X and personality Y. Science International (Lahore), 25(3), 611-617.

27. Irimia-Dieguez, A., Medina-Lopez, C., \& Alfalla-Luque, R. (2015). Financial management of large projects: A research gap. Procedia economics and finance, 23, 652-657. https://doi.org/10.1016/S2212-5671(15)00495-5

28. Jha, K., \& Iyer, K. (2006). Critical factors affecting quality performance in construction projects. Total Quality Management and Business Excellence, 17(9), 1155-1170. https://doi.org/10.1080/14783360600750444

29. Kaminsky, J., \& Zerjav, V. (2016). Relational Governance as Mediator Of Contractual Governance In Public Private Partnership. EPOS.

30. Keegan, A., \& Turner, J. R. (2001). Quantity versus quality in project-based learning practices. Management learning, 32(1), 77-98. https://doi.org/10.1177/1350507601321006

31. Khan, A. S., \& Rasheed, F. (2015). Human resource management practices and project success, a moderating role of Islamic Work Ethics in Pakistani project-based organizations. International Journal of Project Management, 33(2), 435-445. https://doi.org/10.1016/j.ijproman.2014.08.006

32. Khan, K., Abbas, M., Gul, A., \& Raja, U. (2015). Organizational justice and job outcomes: Moderating role of Islamic work ethic. Journal of Business Ethics, 126(2), 235-246. https://doi.org/10.1007/s10551-013-1937-2

33. Khan, N. A., \& Rasheed, A. (2016). Human rights and social work: A study of two disciplines. Human rights, 1(5).

34. Khang, D. B., \& Moe, T. L. (2008). Success criteria and factors for international development projects: A lifecycle-based framework. Project management journal, 39(1), 72-84. https://doi.org/10.1002/pmj.20034

35. Klakegg, O. J. (2009). Pursuing relevance and sustainability: Improvement strategies for major public projects. International journal of managing projects in business.

36. Koops, L., Bosch-Rekveldt, M., Coman, L., Hertogh, M., \& Bakker, H. (2016). Identifying perspectives of public project managers on project success: Comparing viewpoints of managers from five countries in North-West Europe. International Journal of Project Management, 34(5), 874-889. https://doi.org/10.1016/j.ijproman.2016.03.007

37. Ma, H., Zeng, S., Lin, H., \& Zeng, R. (2020). Impact of Public Sector on Sustainability of Public-Private Partnership Projects. Journal of Construction Engineering and Management, 146(2). https://doi.org/10.10 61/(ASCE)CO.1943-7862.0001750

38. Maher, M., \& Andersson, T. (2000). Corporate governance: effects on firm performance and economic growth. Available at SSRN 218490. https://doi.org/10.2139/ssrn.218490

39. Marri, M. Y. K., Sadozai, A. M., Zaman, H. M. F., \& Ramay, M. I. (2012). The impact of Islamic work ethics on job satisfaction and organizational commitment: a study of agriculture sector of Pakistan. International Journal of Business and Behavioral Sciences, 2(12), 32-45.

40. Meyers, M. C., van Woerkom, M., \& Bakker, A. B. (2013). The added value of the positive: A literature review of positive psychology interventions in organizations. European Journal of Work and Organizational Psychology, 22(5), 618-632. https://doi.org/10.1080/1359432X.2012.694689

41. Mir, F. A., \& Pinnington, A. H. (2014). Exploring the value of project management: linking project management performance and project success. International Journal of Project Management, 32(2), 202-217. https://doi.org/10.1016/j.ijproman.2013.05.012

42. Mullaly, M. (2006). Longitudinal analysis of project management maturity. Project management journal, 37(3), 6273. https://doi.org/10.1177/875697280603700307

43. Muller, R. (2011). Project governance. Strategic Direction. https://doi.org/10.1108/sd.2011.05627bae.001

44. Müller, R., Glückler, J., \& Aubry, M. (2013). A relational typology of project management offices. Project management journal, 44(1), 59-76. https://doi.org/10.1002/pmj.21321

45. Müller, R., \& Jugdev, K. (2012). Critical success factors in projects: Pinto, Slevin, and Prescott-the elucidation of project success. International journal of managing projects in business. https://doi.org/10.1108/1753 8371211269040

46. Müller, R., \& Lecoeuvre, L. (2014). Operationalizing governance categories of projects. International Journal of Project Management, 32(8), 1346-1357. https://doi.org/10.1016/j.ijproman.2014.04.005

47. Müller, R., \& Turner, R. (2007). The influence of project managers on project success criteria and project success by type of project. European management journal, 25(4), 298-309. https://doi.org/10.1016/j.emj.2007.06.003

48. Müller, R., \& Turner, R. (2010). Leadership competency profiles of successful project managers. International Journal of Project Management, 28(5), 437-448. https://doi.org/10.1016/j.ijproman.2009.09.003

49. Müller, R., Zhai, L., Wang, A., \& Shao, J. (2016). A framework for governance of projects: Governmentality, governance structure and projectification. International Journal of Project Management, 34(6), 957-969. https://doi.org/10.1016/j.ijproman.2016.05.002 
50. Olateju, A. T., Kuntz, J., \& Nilakant, V. (2018). Linking high-performance work practices and project success: employee engagement matters. Paper presented at the Academy of Management Proceedings. https://doi.org/10.5 465/AMBPP.2018.14890abstract

51. Othman, A. S., Rahman, N. M. t. A., Malek, Z. A., \& Osman, A. R. (2004). Organizational Commitment and work ethics: An empirical assessment in a Malaysian context. Retirado de http://faculty. kfupm. edu. sa/coe/sadiq/proceedings/SCAC2004/toc/htm a, 2.

52. Papke-Shields, K. E., Beise, C., \& Quan, J. (2010). Do project managers practice what they preach, and does it matter to project success? International Journal of Project Management, 28(7), 650-662. https://doi.org/10.10 16/j.ijproman.2009.11.002

53. Parboteeah, K. P., Paik, Y., \& Cullen, J. B. (2009). Religious groups and work values: A focus on Buddhism, Christianity, Hinduism, and Islam. International Journal of Cross Cultural Management, 9(1), 51-67. https://doi.org/10.1177/1470595808096674

54. Pettijohn, C., Pettijohn, L., \& Taylor, A. J. (2008). Salesperson perceptions of ethical behaviors: Their influence on job satisfaction and turnover intentions. Journal of Business Ethics, 78(4), 547-557. https://doi.org/10.1007/s10551007-9367-7

55. Pinto, M. B., \& Pinto, J. K. (1990). Project team communication and cross-functional cooperation in new program development. Journal of Product Innovation Management: an international publication of the product development \& management association, 7(3), 200-212. https://doi.org/10.1111/1540-5885.730200

56. Posthuma, R. A., Campion, M. C., Masimova, M., \& Campion, M. A. (2013). A high performance work practices taxonomy: Integrating the Literature and directing future research. Journal of management, 39(5), 1184-1220. https://doi.org/10.1177/0149206313478184

57. Rice, G. (1999). Islamic ethics and the implications for business. Journal of Business Ethics, 18(4), 345-358. https://doi.org/10.1023/A:1005711414306

58. Sauser, B. J., Reilly, R. R., \& Shenhar, A. J. (2009). Why projects fail? How contingency theory can provide new insights-A comparative analysis of NASA's Mars Climate Orbiter loss. International Journal of Project Management, 27(7), 665-679. https://doi.org/10.1016/j.ijproman.2009.01.004

59. Schwaber, K. (2004). Agile project management with Scrum: Microsoft press. https://doi.org/10.1007/11499053 47

60. Seligman, M. E., \& Csikszentmihalyi, M. (2014). Positive psychology: An introduction Flow and the foundations of positive psychology (pp. 279-298): Springer. https://doi.org/10.1007/978-94-017-9088-8 18

61. Shenhar, A. J., Dvir, D., Levy, O., \& Maltz, A. C. (2001). Project success: a multidimensional strategic concept. Long range planning, 34(6), 699-725. https://doi.org/10.1016/S0024-6301(01)00097-8

62. Tishler, A., Dvir, D., Shenhar, A., \& Lipovetsky, S. (1996). Identifying critical success factors in defense development projects: A multivariate analysis. Technological forecasting and social change, 51(2), 151-171. https://doi.org/10.1016/0040-1625(95)00197-2

63. Too, E. G., \& Weaver, P. (2014). The management of project management: A conceptual framework for project governance. International Journal of Project Management, 32(8), 1382-1394. https://doi.org/10.1016/j.ijpr oman.2013.07.006

64. Turner, J. R. (2006). Towards a theory of project management: The nature of the project governance and project management. International Journal of Project Management, 2(24), 93-95. https://doi.org/10.1016/j.ijp roman.2005.11.008

65. Usman, M., Shahzad, K., \& Khan, K. (2015). Islamic Work Ethics (IWE): A review of litrature and directions for future research. Journal of Islamic Business and Management, 219(3327), 1-28.

66. Walker, D., \& Lloyd-Walker, B. (2014). Client-side project management capabilities: dealing with ethical dilemmas. International journal of managing projects in business, 7(4), 566-589. https://doi.org/10.1108/IJMPB08-2013-0036

67. Wickramasinghe, V., \& Liyanage, S. (2013). Effects of high performance work practices on job performance in project-based organizations. Project management journal, 44(3), 64-77. https://doi.org/10.1002/pmj.21342

68. Winch, G. M. (2001). Governing the project process: a conceptual framework. Construction management and economics, 19(8), 799-808. https://doi.org/10.1080/01446190110074264

69. Yousef, D. A. (2000). Organizational commitment as a mediator of the relationship between Islamic work ethic and attitudes toward organizational change. Human relations, 53(4), 513-537. https://doi.org/10.1177/0018 726700534003

70. Zupan, N., \& Kaše, R. (2007). The role of HR actors in knowledge networks. International Journal of Manpower, 28(3-4), 243-259. https://doi.org/10.1108/01437720710755236

71. Zwikael, O., \& Smyrk, J. (2011). An engineering approach for project scoping. Paper presented at the 2011 IEEE 18th International Conference on Industrial Engineering and Engineering Management. https://doi.org/10.110 9/ICIEEM.2011.6035592 